\title{
Sciendo
}

Administration, vol. 70, no. 1 (2022), pp. 75-82

doi: 10.2478/admin-2022-0006

\section{Education, 2021}

\author{
Joanna O'Riordan \\ Institute of Public Administration, Ireland
}

The year 2021 was without doubt another very challenging one for anyone involved in education. The Covid-19 pandemic once more dominated the sector, with the year both beginning and ending with discussions in respect of the safety of schools, the possibility of school closures and the format the state examinations should take. The year began with what for some second-level students transpired to be three and a half months of remote learning and concluded with the Covid19 Omicron variant contributing to further talk of lockdowns, ongoing discussions in respect of the 2022 state examinations and fluctuating guidelines in respect of close contacts.

\section{School closures}

In early January it was announced by Minister Norma Foley, TD, that the vast majority of schoolchildren would not return to school after the Christmas holidays. It was noted that this was due to public health advice to reduce mobility in the community, notwithstanding the fact that it was generally acknowledged that schools are safe environments. It was indicated initially that the transition to remote learning would be for a period of three weeks.

Engagement between Department of Education officials and school management bodies and trade unions continued in an effort to maintain in-person learning for pupils with special educational needs (SEN) and Leaving Certificate students. However, within days these 
discussions were in disarray, with a number of school principals indicating that they would not open their schools to accommodate inperson learning by sixth-year students only. It was also indicated that further discussion was needed in respect of the 23,000 schoolchildren, or 4 per cent of the total cohort, categorised as having SEN (O'Brien et al., 2021). This impasse continued throughout the month, with the Department of Education indicating in a hard-hitting statement on 19 January that a phased return for children with SEN to in-school learning in mid January would 'regrettably not be possible owing to a lack of cooperation by key staff unions in the primary sector' (Department of Education, 2021f). From the perspective of the Irish National Teachers' Organisation (INTO), the representative body of primary schoolteachers, the move to open schools for children with SEN was being rushed. While the INTO acknowledged progress in respect of pregnant teachers and special educational needs assistants (SNAs) and the position of staff who lack childcare for their own school-age children, the organisation suggested there had been 'no movement' on health-and-safety assessments, higher-priority access to vaccines, serial Covid testing, or assessing the level of demand for school-based SEN services given what they reported was anecdotal evidence of concern amongst parents of SEN children (INTO, 2021).

However, following further intensive engagement with the trade unions representing teachers and SNAs, the government announced that special schools would reopen on 11 February, with students attending on a 50 per cent basis to allow for reduced numbers within the school setting, and that on 22 February special classes in mainstream schools would reopen to pupils. The department also announced that an allowance of twenty hours of home tuition would be made available to SEN children to support their education and/or care needs. The scheme, which was available until the end of April, while supplementary to remote learning, was in recognition that remote learning may not always be suitable for children with SEN. Participation in the programme was voluntary for families, teachers and SNAs. However, there was some frustration expressed among parents of children with severe and profound learning difficulties that the return to classroom learning would only be on a part-time basis (O'Kelly, 2021).

For all other schoolchildren the return to school proceeded on a phased basis. Children up to second class in primary school and finalyear Leaving Certificate students returned to the classroom on 1 March. Children in special schools also returned to full-time hours on 
this date. This was followed on 15 March by the return of all remaining primary schoolchildren and fifth-year second-level students. The remainder of post-primary students returned on 12 April following the Easter break and over three months of remote learning. In an effort to mitigate the impact of Covid-19 on all children, the government in May announced a doubling of funding to $€ 40$ million for summer programmes. In the past, summer programmes were only available to special schools, pupils in special classes in primary schools, and designated DEIS (Delivering Equality of Opportunity in Schools) schools. However, the announcement extended the option of a summer programme to all primary and post-primary schools, while also providing for the possibility of a home-based programme for children with complex needs where their schools were not providing a school-based programme.

Subsequently, in September it was announced that a new Covid Learning and Support Scheme (CLASS) would be implemented. The aim of the scheme is to mitigate the impact of Covid-19 school closures to students' learning and well-being. Under the scheme, every school in the academic year 2021-2 will receive an allocation of additional teaching hours, which they may use in accordance with the needs of their students. This will enable schools to identify students most at risk of learning loss arising from the recent disrupted school experience, and to put in place specific, targeted supports to help these students. It was further noted by the Department of Education (2021) that the Inspectorate would continue to carry out research on the impact of students' disrupted learning experiences on student learning and development.

\section{The Leaving and Junior Certificate exams}

Throughout the first half of the year the advisory group of stakeholders on planning for state examinations, established in 2020, continued to meet in order to plan for the Leaving and Junior Certificate exams. From the outset the government indicated that while there would be examinations, alternative options would also be made available to students. In late February Minister Foley confirmed that Leaving Certificate 2021 examinations would proceed in June, with students also having the alternative option of applying for grades accredited by the State Examinations Commission (SEC), to be known as SEC-Accredited Grades. The results from both the written exams and the accredited grades would have equal standing. It was further 
noted that oral examinations, cancelled in 2020 , would be held, though the holding of practical examinations would not be possible in all subjects due to public health considerations. Providing for accredited grades required legislation in order to confer power on the SEC to run such a system. The legislation was published by the Department of Education in April and progressed rapidly through the Houses of the Oireachtas, being signed into law in late May.

At the same time as the decision was made about the Leaving Certificate, it was also announced that the Junior Certificate exams would be cancelled and replaced by school-based assessment and a Department of Education certificate of completion of the junior cycle. It was noted by the department that this was based on public health advice, which recommended not holding the Leaving and Junior Certificate exams concurrently.

Information released by the SEC in April (O'Brien, 2021) indicated that the vast majority of Leaving Certificate students were opting to sit written exam papers in June in some or all subjects in addition to receiving accredited grades. The figures show that 87 per cent of the 61,125 candidates were choosing a combination of both written exams and accredited grades, with 6 per cent opting for accredited grades only, and just 2 per cent choosing written exams only. Further analysis of the figures suggest that many students were concentrating their efforts on a select number of subjects and, understandably, seeking to maximise their grades through an optimum combination of written exams and accredited grades. In the regular or established Leaving Cert exams, Irish was the least popular written exam, with 58 per cent of those eligible choosing to sit it, followed by French and German (both 69 per cent). A large majority of eligible students intended to sit English (81 per cent) and maths (84 per cent), while the highest takeup of the option to sit written exams was in the science and technology area, including physics ( 87 per cent), chemistry ( 88 per cent) and applied maths (96 per cent).

Leaving Certificate results were available on 3 September, two weeks later than the traditional date in mid August but within the required time frame for Central Application Office admission to higher and further education. The results of each individual student comprise the best results they received from examinations or accredited grades on a subject-by-subject basis, though without indicating from which method the result was derived. Students received their results directly on the Candidate Self Service Portal. 
Given the assessment approach used, the SEC believes that the 2021 exam outcomes are not comparable with the outcomes from before 2020. In particular, grade inflation, while not as high as in 2020, was still, on average, across all subjects, 2.6 per cent, with concerns expressed on the impact this would have on applications for third-level places (Casey, 2021). In terms of accredited grades, the national standardisation process saw one in four school estimates change - 5.9 per cent went up and 16.9 per cent moved down (Casey, 2021). While historical school-by-school data based on past performance in Leaving Certificate exams were not used, historical data at a national level were used to determine the appropriate distributions of results.

\section{Special needs education}

Special classes are part of a continuum of educational provision for children with complex special needs. They enable them to be educated in smaller class groups within their local mainstream school. Following announcements in Budget 2022 in respect of the recruitment of special needs teachers, the government made a commitment to creating an additional 287 special classes with 1,700 places in 2022. The provision of the special classes will follow engagement with schools and demographic planning.

In September guidelines were issued by the Department of Education on the use of reduced days for children with special needs. The guidelines are aimed at ensuring that the use of reduced schooldays is limited solely to circumstances where it is absolutely necessary. In particular, the guidelines specify that the consent of a parent or guardian to the reduced schoolday is required and that it should never be perceived as a permanent arrangement. In addition, from January 2022 schools will be required to notify Tusla Education Support Service when a reduced schoolday is put in place for a pupil.

A full review of the Education for Persons with Special Educational Needs Act 2004 was announced by Minister of State Josepha Madigan, TD, in December (Department of Education, 2021e). The purpose of the review is to ensure that legislation on education for students with additional needs is up to date, fully operational and reflective of the lived experiences of students and families. The review will begin in January 2022 with the establishment of a steering group and advisory group to oversee the process. There will be a formal consultation process and it is envisaged the review will take a year. 


\section{School funding}

In October the publication of the National Development Plan 20212030 saw $€ 4.4$ billion in capital funding provided for investment in school infrastructure for the period up to 2025 (Department of Education, 2021c). The investment will be aimed at adding school capacity to cater for demographic changes and provision for children with SEN, and to help transition the school system for an era of net zero carbon by 2050. According to the Department of Education (2021b), it is intended to deliver an average of 150-200 new and refurbished school projects annually up to 2025 .

Later in October it was announced that core investment in the school system would increase by half a billion euro to $€ 9.2$ billion (Department of Education, 2021a). An increase in funding of over 20 per cent for the DEIS programme was the main feature of the announcement. Funding will also be provided for an additional 350 teachers, 980 special education teachers and a further 1,165 SNAs.

\section{Digital schools}

The development of a new Digital Strategy for Schools was announced in April, replacing the existing 2015-20 strategy. The aim of the strategy is to set out the Department of Education's policy on the use of digital technologies in teaching, learning and assessment. A consultative group involving key stakeholders will be established and a consultation framework developed. The upskilling of teachers will continue to be a key priority in the new strategy.

Separately, during the year two digital projects were announced, which will be funded under the National Recovery and Resilience Facility (NRRP). The NRRP was developed by the government so that Ireland can access funding under the EU's Recovery and Resilience Facility, part of Next Generation EU, the EU's response to the Covid-19 pandemic. It was announced by Minister Foley (Department of Education, 2021d) that funding would be paid to all recognised schools in the free education system to invest in digital infrastructure to support students who are most at risk of educational disadvantage through the digital divide, with DEIS schools receiving double the amount of funding provided to non-DEIS schools. The second project will ensure that all primary schools will be provided with high-speed broadband connectivity by early 2023 . 


\section{Other developments}

A new Statement of Strategy 2021-2023 for the Department of Education was published in June. This follows on from the appointment in 2020 of Minister Foley. Government departments are required to prepare a new strategy statement on the appointment of a new minister. One of the main strategic actions identified under the new strategy is to support school communities through and post Covid-19, especially those students at risk of educational disadvantage.

The Department of Education's STEM Education Policy Statement runs from 2017 to 2026. It aims at promoting STEM (science, technology, engineering and mathematics) throughout the education system. Three phases of implementation were determined at the outset. However, the second phase of implementation was delayed by Covid-19. A consultation process in respect of this was announced in late December.

A report by the Comptroller and Auditor General into financial management in a sample of five education and training boards (ETBs) was published in March. The ETB sector has been undergoing a period of major change since the establishment of the ETBs in 2013. A programme of improvement in the financial governance and reporting systems is ongoing.

A two-year action research project aimed at supporting small rural schools was launched in July. The project aims to encourage small schools to cluster together in local groups, enabling them to collaborate, share resources, identify common challenges and trial solutions. The project will be overseen by a steering group of stakeholders. Small schools are defined for statistical purposes as having four mainstream teachers or fewer. Schools meeting this definition constitute 44 per cent of all primary schools - around 1,360 individual schools - and account for 14.2 per cent of all students.

\section{References}

Casey, J. (2021). Unprecedented circumstances shaped Leaving Cert 2021. Retrieved from https://www.irishexaminer.com/opinion/comment analysis/arid-40372310.html [20 January 2022].

Department of Education. (2021a). Minister Foley and Madigan announce details of $€ 9.2$ billion education funding in Budget 2022. Department of Education press release, 13 October 2021. Dublin: Department of Education. 
Department of Education. (2021b). Minister Foley and Madigan launch Covid learning and supports scheme for measures to mitigate learning loss. Department of Education press release, 8 September 2021. Dublin: Department of Education.

Department of Education. (2021c). Minister Foley and Madigan welcome the 5 -year investment of 4.4 billion in school infrastructure. Department of Education press release, 4 October 2021. Dublin: Department of Education.

Department of Education. (2021d). Minister Foley announces issue of $€ 50$ million funding to primary and post primary schools to address the digital divide. Department of Education press release, 6 December 2021. Dublin: Department of Education.

Department of Education. (2021e). Minister Josepha Madigan launches review of the Education for Persons with Special Needs Act 2004. Department of Education press release, 20 December 2021. Dublin: Department of Education.

Department of Education. (2021f). Statement from the Department of Education. Department of Education press release, 19 January 2021. Dublin: Department of Education.

Irish National Teachers' Organisation. (2021). Teachers and SNAs call for postponement of schools' reopening. Retrieved from https://www.into.ie/teachers-and-snas-call-for-postponement-of-schoolsreopening.html [20 January 2022].

O'Brien, C. (2021). Most Leaving Cert students opt to sit written exams in June, INTO. Retrieved from https://www.into.ie/teachers-and-snas-call-forpostponement-of-schools-reopening.html [20 January 2022].

O’Brien, C., Bray, J., Bowers, S., \& McGee, H. (2021). Government scraps plans for partial reopening of schools. Retrieved from https://www.irishtimes.com/news/education/government-scraps-plan-forpartial-reopening-of-schools-1.4452315 [20 January 2022].

O'Kelly, E. (2021). Deal agreed for return to special education this month. Retrieved from https:/www.rte.ie/news/coronavirus/2021/0201/1194218covid-19-ireland/ [20 January 2022]. 